\title{
OFFSHOOTS OF KARNATAKA'S FARIM POWER SUBSIDY REGIME
}

KEY WORDS: agenda; feasible; incompetence; subsidy; uninterrupted; win-win situation

\section{Dr. Mahesha, V.*}

Sri. Naveen, G.V.
Chairman, Department of Commerce, Karnataka State Open University, Mysuru- 570006. *Corresponding Author

Research Scholar, Department of Commerce, Karnataka State Open University, Mysuru-570006.

Farm power subsidy figures prominently on the agenda of almost every state government of the country. By including the farm power subsidy regime in their agenda, the states seem to have erroneously convinced themselves that they had contributed to the cause of agriculture and agriculturists. If their conviction is right, by now the problems faced by our agriculturists must have been solved many times over. But the problems have not been solved yet although our agriculture is characterized by small and fragmented landholdings. The reasons are not far to seek. The policy targeted marginal farmers and small farmers but big farmers somehow managed to gain a toehold, thereby reducing the pie earmarked for the marginal and small farmers. The regime rendered it easier for the political and permanent executives to evade responsibilities, adding to the woes of the ESCOMS or electricity supply companies. To make matters worse, government failed to release subventions to the Escoms promptly. Upon inquiry, the researcher was convinced that the farmer-consumers would not oppose a pro rata levy on the power consumed, provided quality power was supplied to them uninterruptedly. This would also minimize the opportunities available to vested interests to pilfer power. It is true that the farm power subsidy regime provides scope to the political and permanent executives to evade responsibilities, adding to the incompetence of Escoms. But there is a way out -- the state government, utility companies and farmer-users should devise a set of politically and financially feasible and socially acceptable alternatives to address the problem. A win-win situation will emerge as a result.

\subsection{Theoretical background of the topic}

lLike most states in India, Karnataka has been supplying electricity at a subsidized cost or free of cost to its farming community. The intention of the government is understandable. Agriculture has been the primary sector of the country's economy. A big chunk of agriculturists in the country is into subsistence agriculture. As importantly, it keeps the biggest chunk of the country's masses employed. Supporting agriculture is essential to ensure the country's food security too. In the circumstances, the government of Karnataka decided to supply electricity at a subsidized price to small and marginal farmers to help them sustain their farming activities. The government believed that the supply would at least help the small and medium farmers maintain their livelihood. Subsidized electricity soon gave way to free electricity. Alongside, the incentive began to benefit the big or large farmers more which was never the intention of the government.

\subsection{Statement of the problem}

The free power supply scheme turned out to be a perverse incentive and thus boomeranged on the government. Farmers took the precious resources, namely, water and electricity, for granted.They persisted with their energy-guzzling pump sets which were becoming less efficient by the day. The toxic gases the pump sets spewed out damaged the environment. Farmers began to raise heavy water crops even if the soil did not suit such crops. To top it all, the skewed outcome of the subsidised electricity / free electricity regime ended up benefiting the large farmers more. Thus, some of the offshoots of the farm power subsidy regime have proved counterproductive.The present study seeks to identify the offshoots.

\subsection{Review of literature}

In the following paragraphs, a few pieces of literature on the subject are reviewed.

1. Associations representing industries and consumers strongly differed with the Chamundeshwari Electricity Supply Corporation (CESC) on its decision to raise the tariff by INR 1.44 a unit for all categories of consumers (The Hindu, 2021). CESC sought the tariff escalation to cover the revenue deficit of INR 1,005 crores, looming at the end of the financial year 2021-22. The CESC had submitted its tariff revision proposal to the Karnataka Electricity Regulatory Commission (KERC). The latter elicited the views of the public and other stakeholders like industries and associations on the move, at the Deputy Commissioner's office at Mysore. The boss of CESC justified the hike by citing the performance of his company, the new initiatives it had launched and the measures it had taken for minimising the transmission and distribution (T\&D) losses, among others. The CESC, whose jurisdiction extends to Mysuru, Mandya, Chamarajnagar, Hassan and Kodagu districts, required INR 6,024.12 crore for its outlays. However, it hoped to realise only INR 5,019.12 crore from consumers, thus leading to a deficit of INR 1,005 crores. The explanation furnished by Escoms is generally taken with a pinch of salt by the consumers. The reason is that the so-called T\&D losses represent a prominent $\mathrm{X}$ factor in the Escom parlance and can be conveniently placed under a residual category. Incidentally, all embarrassing and inconvenient issues can be camouflaged, courtesy this category. None has been able to decompose the T\&D losses accurately, for obvious reasons!

2. Ravindra Prabhu was critical of the hike of 63.32 paise per unit sought by CESC to overcome the deficit of INR 475.50 crores it would incur in 2020-21 (Ravindra, 2021). In 2019-20, it sought a hike of 99 paise to address the deficit. In the two years gone by, the CESC's shortfall had been on the rise. It led the management to seek a higher revision for fiscal 2021. In the circumstances, the management sought approval of its proposal to raise the tariff by INR 1.44 a unit, including fixed costs. According to the CESC, the cost of power purchase would be INR 4,206.93 crores for fiscal 2022. In fiscal 2021 , the cost incurred for the purchase was INR 3,611.91 crores. However, the KIADB Industrial Area Manufacturers' Association objected to the proposal. It called the move "antiindustry", "anti-people" and unwarranted. It urged the Chairman of KERC to reject the proposal outright. The Association said that the CESC had proposed to purchase power at an exorbitant price of INR 8.51 to INR 12.81 per unit from its own and Central government power generating companies. If approved, it would lead to large-scale closure of small scale industries, which were already faced with a crisis. Mutual recriminations and accusations have become commonplace when a hike in power tariff is sought by the 
Escoms annually. Eventually, the two sides agree to meet halfway, and the issue is forgotten soon after until it crops up the next year when the Escoms seek another hike. This routine is not what the power sector reforms envisaged. What the reforms envisaged was assured supply of quality power at competitive prices to the consumer.

3. According to Suresh Kumar Jain , the proposed hike of 63.32 paise per unit to overcome the deficit of INR 475.50 crores the CESC would incur in 2020-21 was unjustified at least in the case of small scale industries (LT 5 and HT 2 categories) (Suresh, 2021). Load-shedding and unscheduled interruptions had already begun to result in loss of man hours and loss of production for the small players. The survival of SSIs in the competitive market was at stake. The various concessions being extended to the small scale sector will be of no avail if load-shedding and unscheduled interruptions mar their operations. The erratic supply of power, that too of inconsistent quality and unscheduled power interruptions have only led many SSI units to wonder whether the so-called concessions and other carrots being extended to the SSI sector represent mere tokenism on the part of the government.

4. Dinesh and Narayanamoorthy argue that withdrawal of power subsidies in the agriculture sector has been a contentious issue in India for decades (Dinesh \& Narayanamoorthy, 2020). Free power and tariffs based on the connected load lead farmers to use ground water inefficiently. The researchers argue that a pro rata tariff regime for electricity use in the farm sector will reduce the demand for electricity for the purpose of lift irrigation. Such a tariff will prove socio-economically viable, raise farm economy and ensure that the power sector is not affected.ICT should be used to reduce the transaction cost associated with metering of agro wells. Free power for the farm sector and remunerative prices for major cereals have led to rapid depletion of groundwater, adversely affecting the resourcepoor farmers. Absence of well-defined property rights in respect of groundwater lead to its over-exploitation and inefficient use. To improve the sustainability of groundwater use, the researchers offer two solutions. They are pro rata pricing of electricity and a functional water rights system. Prepaid energy meters or automatic metering infrastructure can be used to introduce pro rata pricing and to monitor the energy consumed by individual farmers. This can be supplemented by energy rationing. The transaction cost of metering can be reduced significantly with the help of ICT. However, a tariff regime that promotes efficient use of water and does not pinch the farmer needs to be worked out. The state government could transfer a cash subsidy directly to the bank accounts of eligible electricity consumers in the farm sector, based on their actual consumption of electricity. This will help the state power utilities to reprice power supplied to various consumer categories like domestic, industrial and agricultural, based on financial prudence. Frankly speaking, the state governments of the country crossed a Rubicon by deciding to supply free power or subsidised power to the farming community. There is no going back on it since the governments must be politically correct. They have no alternative but to make the best of a bad job.

\subsection{Research gap}

The researchers have come out with some telling revelations on the topic. One researcher has hit the nail on the head by stating that the so-called T\&D losses represent a prominent $\mathrm{X}$ factor in Escom circles, and the said losses can be conveniently placed under a residual category. Incidentally, all embarrassing and inconvenient issues can be camouflaged, courtesy this category. Dinesh and Narayanamoorthy rightly remark that the state governments of the country crossed a Rubicon by deciding to supply free power or subsidised power to the farming community. There can be no going back on it since the governments must be politically correct. The government has no alternative but to make the best of a bad job. This skewness should be addressed. Otherwise, it will continue to be a "farming-oriented" relief and nothing more. What is clear from what the learned researchers have said is that the farm power subsidy regime has engendered certain undesirable offshoots. This study proposes to identify the offshoots.

\subsection{Scope of the present study}

The study covers the implications of Karnataka state's farm power subsidy regimefor the period FY 2015 - FY 2020. Specifically, it will dwell on the role of Chamundeshwari Electricity Supply Corporation (CESCO) in the farm power subsidy space. The study considers two categories of respondents associated with the topic. They are CESCO officers, numbering 50 and farmer-consumers, numbering 100. The latter are into farming in the five districts serviced by CESCO. The study covers the period FY 2015 - FY 2020. To this study, farmer-consumers are those who have installed irrigation pump sets of up to and inclusive of $10 \mathrm{HP}$ at their farms and are designated by CESCO as LT-4 (a) consumers for tariff purposes.

\subsection{Objectives of the study}

The objective of the study is to examine the offshoots of the farm power subsidy regime of Karnataka state.

\subsection{Hypothesis proposed to be tested}

The study proposes to test the following hypothesis:

"The regressive electricity subsidy regime has helped big farmers, to reap more from the regime than small and marginal farmers"

\subsection{Research design \\ 1.8.1 Research methodology}

By intent, this research is a descriptive research. Going by the methods of study, this research can be described as a survey or a social survey, to be more specific.

\subsubsection{Sources of data}

Data required for the research has been collected from primary as well as secondary sources. Primary data has been collected from two categories of respondents, namely, 100 farmer-consumers and 50 CESCO officers.Secondary data has been collected from the annual reports of CESCO, the publications of the department of energy of the government of Karnataka and the financial press, among others.

\subsubsection{Sampling plan}

Farmer-consumers: Simple random sampling under the probability sampling method was undertaken, to select the 100 farmer-consumers from the 300 farmer-consumers hailing from the jurisdiction serviced by CESCO. To ensure true randomness, the researcher has used the table of random numbers.

CESCO officers: The researcher opted for purposive or judgement sampling under the non-probability method, since the sample units, namely the 50 CESCO officers, had to conform to a pre-determined criterion. The researcher selected such officers who, in his judgement, were the most appropriate ones for the present study.

\subsubsection{Data collection instruments}

Interview schedules, specially designed for the purpose, were administered to the respondents for collection of primary data.

\subsubsection{Data processing and analysis plan}

Manual as well as mechanical methods were employed for data processing. As for the latter, the researcher used Microsoft Excel 365 for data analysis, reporting and deployment. To collect primary data, a 5-point Likert scale was used to elicit the respondents' replies to the queries 
raised in the Interview Schedule.

\subsubsection{Limitations of the study}

Primary data has also been deduced through constant topicoriented discussions with the respondents. It is possible that a certain degree of subjectivity, even if negligible, has influenced their views. But the researcher is confident that the level of subjectivity will be too insignificant to affect the accuracy of the findings of the study.

\subsection{CESCO officers}

In the following paragraphs, the primary data collected from the 50 CESCO officer respondents on the offshoots of the farm power subsidy is analysed.

\subsubsection{Piecemeal subvention of the Escoms by the government}

One of the alleged offshoots of the farm power subsidy regime is the piecemeal subvention of the Escoms by the government. Hence the researcher sought to know from the respondents if they would agree with the statement that one of the offshoots of the farm power subsidy regime is the piecemeal subvention of the Escoms by the government. The respondents' agreement / otherwise with the statement is expressed at five levels, namely, SA=Strongly Agree, $\mathrm{A}=$ Agree, $\mathrm{N}=$ Neutral, $\mathrm{D}=$ Disagree and $\mathrm{SD}=$ Strongly Disagree. These levels are assigned the values $1,2,3,4$ and 5 respectively. Their levels of agreement with the statement are reflected in the following Table and Figure.

Table-1

Piecemeal subvention of the Escoms by the government

\begin{tabular}{|l|c|c|}
\hline Levels of Agreement (Values) & Frequency & Percentage \\
\hline Strongly Agree (1) & 13 & 26 \\
\hline Agree (2) & 24 & 48 \\
\hline Neutral (3) & 7 & 14 \\
\hline Disagree (4) & 5 & 10 \\
\hline Strongly Disagree (5) & 1 & 2 \\
\hline Total & $\mathbf{5 0}$ & $\mathbf{1 0 0}$ \\
\hline
\end{tabular}

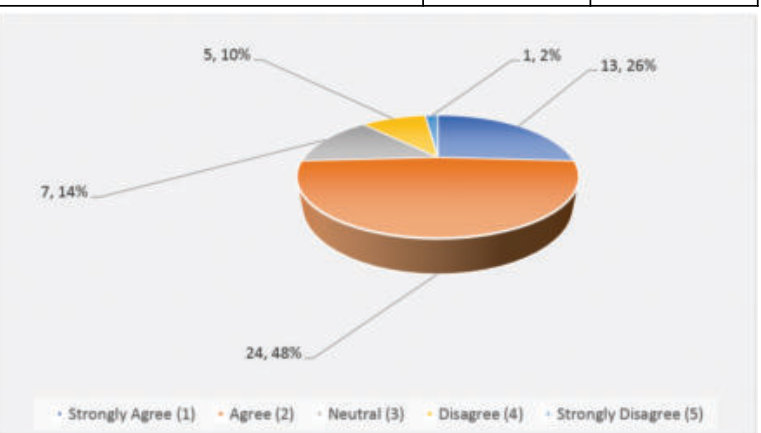

Figure-1

Piecemeal subvention of the Escoms by the government

26 percent of the respondents strongly agree with the statement that one of the offshoots of the farm power subsidy regime is the piecemeal subvention of the Escoms by the government. 48 percent agree with the statement that one of the offshoots of the farm power subsidy regime is the piecemeal subvention of the Escoms by the government. 10 percent disagree with the statement that one of the offshoots of the farm power subsidy regime is the piecemeal subvention of the Escoms by the government. Two percent strongly disagree with the statement that one of the offshoots of the farm power subsidy regime is the piecemeal subvention of the Escoms by the government. 14 percent remain neutral.

74 percent agree with the statement that one of the offshoots of the farm power subsidy regime is the piecemeal subvention of the Escoms by the government.
1.9.2The regressive electricity subsidy regime has helped big farmers, to reap more from the regime than small and marginal farmers

Among the alleged offshoots of the farm power subsidy regime is that the regressive electricity subsidy regime has helped big farmers, to reap more from the regime than small and marginal farmers. Hence the researcher sought to know from the respondents if they would agree with the statement that an offshoot of the regressive electricity subsidy regime has helped big farmers, to reap more from the regime than small and marginal farmers. The respondents' agreement / otherwise with the statement is expressed at five levels, namely, SA=Strongly Agree, $\mathrm{A}=$ Agree, $\mathrm{N}=$ Neutral, $\mathrm{D}=$ Disagree and $\mathrm{SD}=$ Strongly Disagree. These levels are assigned the values $1,2,3,4$ and 5 respectively. Their levels of agreement with the statement are reflected in the following Table and Figure.

Table-2

The regressive electricity subsidy regime has helped big farmers, to reap more from the regime than small and marginal farmers

\begin{tabular}{|l|c|c|}
\hline Levels of Agreement (Values) & Frequency & Percentage \\
\hline Strongly Agree (1) & 17 & 34 \\
\hline Agree (2) & 21 & 42 \\
\hline Neutral (3) & 8 & 16 \\
\hline Disagree (4) & 2 & 4 \\
\hline Strongly Disagree (5) & 2 & 4 \\
\hline Total & $\mathbf{5 0}$ & $\mathbf{1 0 0}$ \\
\hline
\end{tabular}

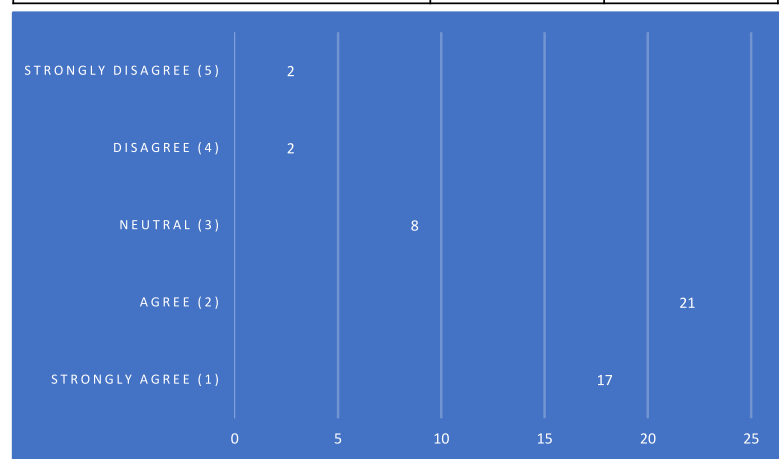

Figure-2

The regressive electricity subsidy regime has helped big farmers, to reap more from the regime than small and marginal farmers

34 percent of the respondents strongly agree with the statement that an offshoot of the regressive electricity subsidy regime has helped big farmers, to reap more from the regime than small and marginal farmers. 42 percent agree with the statement that an offshoot of the regressive electricity subsidy regime has helped big farmers, to reap more from the regime than small and marginal farmers. Four percent disagree with the statement that an offshoot of the regressive electricity subsidy regime has helped big farmers, to reap more from the regime than small and marginal farmers. Four percent strongly disagree with the statement that an offshoot of the regressive electricity subsidy regime has helped big farmers, to reap more from the regime than small and marginal farmers. 16 percent remain neutral.

76 percent agree with the statement that an offshoot of the regressive electricity subsidy regime has helped big farmers, to reap more from the regime than small and marginal farmers.

\subsection{Farmer-consumers}

In the following paragraphs, the primary data collected from the 100 farmer-consumer respondents on the offshoots of the farm power subsidy is analysed. 
1.10.1 Political and permanent executives evade responsibilities thereby raising the incompetence of Escoms

One of the alleged offshoots of the farm power subsidy regime is that the political and permanent executives evade responsibilities thereby raising the incompetence of Escoms. Hence the researcher sought to know from the respondents if they would agree with the statement that one of the offshoots of the farm power subsidy regime is that the political and permanent executives evade responsibilities thereby raising the incompetence of Escoms. The respondents' agreement / otherwise with the statement is expressed at five levels, namely, $\mathrm{SA}=$ Strongly Agree, $\mathrm{A}=$ Agree, $\mathrm{N}=\mathrm{Neutral}$, $\mathrm{D}=$ Disagree and $\mathrm{SD}=$ Strongly Disagree. These levels are assigned the values $1,2,3,4$ and 5 respectively. Their levels of agreement with the statement are reflected in the following Table and Figure.

Table-3

Political and permanent executives evade responsibilities thereby raising the incompetence of Escoms

\begin{tabular}{|l|c|c|}
\hline Levels of Agreement (Values) & Frequency & Percentage \\
\hline Strongly Agree (1) & 22 & 22 \\
\hline Agree (2) & 47 & 47 \\
\hline Neutral (3) & 14 & 14 \\
\hline Disagree (4) & 9 & 9 \\
\hline Strongly Disagree (5) & 8 & 8 \\
\hline Total & $\mathbf{1 0 0}$ & $\mathbf{1 0 0}$ \\
\hline
\end{tabular}

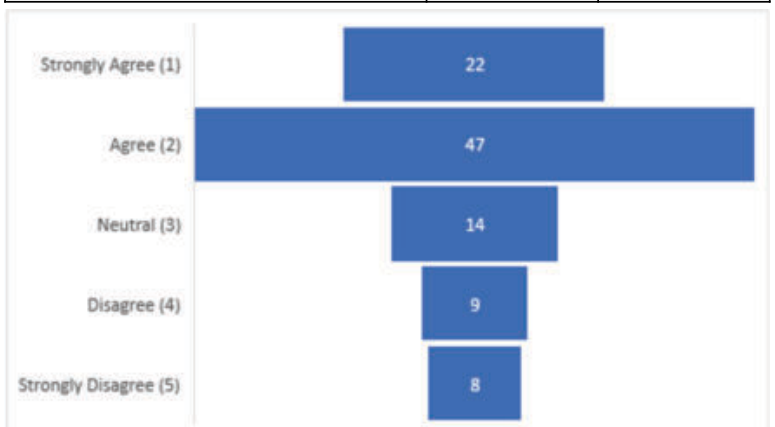

Figure-4.3

Political and permanent executives evade responsibilities thereby raising the incompetence of Escoms

22 percent of the respondents strongly agree with the statement that one of the offshoots of the farm power subsidy regime is that the political and permanent executives evade responsibilities thereby raising the incompetence of Escoms.47 percent agree with the statement that one of the offshoots of the farm power subsidy regime is that the political and permanent executives evade responsibilities thereby raising the incompetence of Escoms. Nine percent disagree with the statement that one of the offshoots of the farm power subsidy regime is that the political and permanent executives evade responsibilities thereby raising the incompetence of Escoms. Eight percent strongly disagree with the statement that one of the offshoots of the farm power subsidy regime is that the political and permanent executives evade responsibilities thereby raising the incompetence of Escoms. 14 percent remain neutral.

69 percent agree with the statement that one of the offshoots of the farm power subsidy regime is that the political and permanent executives evade responsibilities thereby raising the incompetence of Escoms.

1.10.2The regressive electricity subsidy regime has helped big farmers, to reap more from the regime than small and marginal farmers

One of the alleged offshoots of the farm power subsidy regime is that the regressive electricity subsidy regime has helped big farmers, to reap more from the regime than small and marginal farmers.Hence the researcher sought to know from the respondents if they would agree with the statement that an offshoot of the regressive electricity subsidy regime has helped big farmers, to reap more from the regime than small and marginal farmers. The respondents' agreement / otherwise with the statement is expressed at five levels, namely, $\mathrm{SA}=$ Strongly Agree, $\mathrm{A}=$ Agree, $\mathrm{N}=$ Neutral, $\mathrm{D}=$ Disagree and $\mathrm{SD}=$ Strongly Disagree. These levels are assigned the values $1,2,3,4$ and 5 respectively. Their levels of agreement with the statement are reflected in the following Table and Figure.

\section{Table-4}

The regressive electricity subsidy regime has helped big farmers, to reap more from the regime than small and marginal farmers

\begin{tabular}{|c|c|c|}
\hline Levels of Agreement (Values) & Frequency & Percentage \\
\hline Strongly Agree (1) & 19 & 19 \\
\hline Agree (2) & 46 & 46 \\
\hline Neutral (3) & 17 & 17 \\
\hline Disagree (4) & 13 & 13 \\
\hline Strongly Disagree (5) & 5 & 5 \\
\hline Total & 100 & 100 \\
\hline Stronely Aeree (1) & 19 & \\
\hline Anere (2) & 46 & \\
\hline Neutra (3) & n) & \\
\hline Disagee (4) & 13 & \\
\hline stronevi Dasagree (5) & 5 & \\
\hline
\end{tabular}

\section{Figure-4}

The regressive electricity subsidy regime has helped big farmers, to reap more from the regime than small and marginal farmers

19 percent of the respondents strongly agree with the statement that an offshoot of the regressive electricity subsidy regime has helped big farmers, to reap more from the regime than small and marginal farmers. 46 percent agree with the statement that an offshoot of the regressive electricity subsidy regime has helped big farmers, to reap more from the regime than small and marginal farmers. 13 percent disagree with the statement that an offshoot of the regressive electricity subsidy regime has helped big farmers, to reap more from the regime than small and marginal farmers. Five percent strongly disagree with the statement that an offshoot of the regressive electricity subsidy regime has helped big farmers, to reap more from the regime than small and marginal farmers. 17 percent remain neutral.

65 percent agree with the statement that an offshoot of the regressive electricity subsidy regime has helped big farmers, to reap more from the regime than small and marginal farmers.

\subsection{Summary of findings}

In the following paragraphs, a summarised version of the findings arrived at in respect of the two categories of respondents is furnished.

\subsubsection{CESCO officer respondents}

- 74 percent agree with the statement that one of the offshoots of the farm power subsidy regime is the piecemeal subvention of the Escoms by the government.

- 76 percent agree with the statement that an offshoot of the regressive electricity subsidy regime has helped big 
farmers, to reap more from the regime than small and marginal farmers.

\subsubsection{Farmer-consumer respondents}

- 69 percent agree with the statement that one of the offshoots of the farm power subsidy regime is that the political and permanent executives evade responsibilities thereby raising the incompetence of Escoms.

- 65 percent agree with the statement that an offshoot of the regressive electricity subsidy regime has helped big farmers, to reap more from the regime than small and marginal farmers.

\subsection{Conclusions}

Conclusions relate to the hypotheses. They are answers to the research questions.

As already explained, the hypothesis reads as follows:

"The regressive electricity subsidy regime has helped big farmers, to reap more from the regime than small and marginal farmers"

Hence $\mathrm{H}_{0}$ and $\mathrm{H}_{1}$ are as follows:

$\mathrm{H}_{0}$ : The regressive electricity subsidy regime has not helped big farmers, to reap more from the regime than small and marginal farmers

$\mathrm{H}_{1}$ : The regressive electricity subsidy regime has helped big farmers, to reap more from the regime than small and marginal farmers

Based on the primary data collected from the respondents, vide Tables: 2 and 4, a chi-square test was applied to ascertain the association, if any, between the two variables.

The following Table reveals the computation made using MSExcel:

\begin{tabular}{|l|l|c|c|c|}
\hline & & \multicolumn{3}{|c|}{ Observed Values } \\
\hline & \multicolumn{1}{|c|}{ Category } & Yes & No & Total \\
\hline & CESCO officers & 38 & 12 & 50 \\
\hline & Farmer-consumers & 65 & 35 & 100 \\
\hline & Total & 103 & 47 & 150 \\
\hline & & \multicolumn{3}{|c|}{ Expected Values } \\
\hline & \multicolumn{1}{|c|}{ Category } & Yes & No & Total \\
\hline & CESCO officers & 34.3333 & 15.6667 & 50 \\
\hline & Farmer-consumers & 68.6667 & 31.3333 & 100 \\
\hline & Total & 103 & 47 & 150 \\
\hline & & Yes & No & \\
\hline & o-e & 3.6667 & -3.6667 & \\
\hline 2 & & -3.6667 & 3.6667 & \\
\hline & (o-e)^2 & 13.4444 & 13.4444 & \\
\hline & & 13.4444 & 13.4444 & \\
\hline & $\left((\mathrm{o}-\mathrm{e})^{\wedge} 2\right) / \mathrm{e}$ & 0.3916 & 0.8582 & \\
\hline & & 0.1958 & 0.4291 & \\
\hline & CV & 0.5874 & 1.2872 & 1.8746 \\
\hline & $T V$ & & & 3.8415 \\
\hline$p$ & & & 0.1709 \\
\hline
\end{tabular}

The calculated value of $2 \chi$ is 1.8746 , lower than the table value of 3.8415 for an alpha of 0.05 at one degree of freedom. Hence the null hypothesis is not rejected, and the research hypothesis is rejected. $p=0.1709$ is the inverse of the onetailed probability of the chi-squared distribution.

\subsection{Researcher's recommendations}

1. Subvention of the Escoms has not been happening the way it should. Government releases the subvention piecemeal, thereby exposing the Escoms to cash flow problems. If the Escoms must deliver on their promise, the government must deliver on its promise too, by ensuring that the subventions are released promptly. Blaming the Escom (which in this case is CESCO) for not delivering on its promise can by no means be justified in such a case.
2 . It is a fact that the subsidy regime has led the big farmers to reap more from the farm power subsidy regime than the small and marginal farmers.This travesty of justice can be addressed. Government should first meter all IP sets so energy consumption and energy savings can be accounted for.Subsequently, it should apply pro rata tariff to electricity consumed by the farmer-consumers so the demand for power drops.

3. Government should meter electricity consumption for another reason too -- it can accurately monitor electricity usage. It will help the government to initiate steps to minimise pilferage of electricity.

4. It is true that the farm power subsidy regime provides scope to the political and permanent executives to evade responsibilities, adding to the incompetence of electricity supply companies (Escoms). The way out of this is for the state government, utility companies and farmer-users to devise a set of politically and financially feasible and socially acceptable alternatives to address the problem.

\subsection{REFERENCES}

1. Dinesh, K. M., \& Narayanamoorthy, A. (2020). Fixing agricultural power tariff without hurting farmers. International Journal of Water Resources Development, 1-5.

2. Ravindra, P. K. (2021, February 17). CESC seeks hike of $\square 1.44$ a unit to deal with $\square 1,005 \mathrm{cr}$. deficit. (T.Hindu, Interviewer)

3. Suresh, K. J. (2021, February 17). CESC seeks hike of $\square 1.44$ a unit to deal with $1,005 \mathrm{cr}$. deficit. (T.Hindu, Interviewer)

4. The Hindu. (2021, February 17). Karnataka: The Hindu. Retrieved from The Hindu Web site: https://www.thehindu.com/news/national/karnataka/cescseeks-hike-of-144-a-unit-to-deal-with-1005-cr-deficit/article33862602.ece 